\title{
Sectarianism and Its Implications for Pakistan Security: Policy Recommendations Using Exploratory Study
}

\author{
Saima Afzal ${ }^{1}$, Hamid Iqbal ${ }^{2}$, Mavara Inayat ${ }^{2}$ \\ ${ }^{1}$ Department of Peace and conflict studies, National Defence University Islamabad, Pakistan \\ ${ }^{2}$ Department of International Relations, Quaid-i-Azam, University Islamabad, Pakistan
}

\begin{abstract}
Sectarianism is a real threat to Pakistan security. It has created ferocity, unrest and disorder in the society. From the last three decade sectarian conflicts have increased suicide bombings, bomb blasts, assassinations, target killings and terrorist attacks. The sectarian strife has threatened Pakistan economically, sociologically, and politically. Contemporary, there is a need to adopt multiple ways for the progress and prosperity of the country. All the provinces need to think being a Pakistani not like a Sunni, Shia, Deobandi, Ahl-i-Hadith, Qadiani and Mirzai, then no one can harm the unity and the nation. We have mentioned in our findings internal and external factors with various policies recommendations to overcome the sectarian barriers.
\end{abstract}

Keywords: Sectarianism, Internal and External Factors, Pakistan Security, Policy Recommendations.

\section{Introduction}

Sectarianism is not a new phenomenon. It has been present in every society since the dawn of human history on the face of the earth. Nations entered into the new millennium with this unresolved issue. Pakistan is the main victims of sectarianism, which has been a major obstacle in the way of national integration. Before going into detail it is necessary to know what sectarianism?

The world sectarianism is derived from 'sect', which means body of people has diverse views within same religion (Bryan Wilson 1982). Sectarianism means adherence to a particular sect or party, especially in a bigoted or narrow minded manner. In sociological studies sect is the religious study which means a group split from the mainstream religion on the grounds of doctrine (Bryan Wilson 1982). In Islam there are two sects Shia and Sunni whereas Shia are the followers of Ali, son-in-law of Prophet (S.A.W). Sectarianism creates violence in a multiple society like Pakistan. The reason is that people of different ideologies stick to their beliefs and do not compromise with others (Andrew Feenberg 1983). In sectarianism an individual or group adhere to a particular sect or religion, develops the feeling of self righteousness and adopts an attitude of intolerance towards other sects of the same religion (Andrew Feenberg 1983).

The main purpose of this study is to explore how sectarianism is threatening Pakistan's security? How sectarianism is rooted in Pakistani society? Further it describes the role of different religious groups in sectarian violence and how these groups use religion for their own interest? It also elaborates external and internal factors of sectarianism and its implications for national and human security and how it threatens national and human security of Pakistan? There are also conclusionary remarks with some viable solutions for improving greater understanding and how to live in peace in a multiple society like Pakistan?

\section{Background and Motivation}

Sectarianism in Pakistan is the most destabilizing factor for the country's political, social, religious, and security order. It has caused violence, disorder, and unrest in society. From last 30 years onwards, the society has seen number of suicide attacks, bomb blasts, assassination and terrorist act as the result of sectarian conflict. The government sometimes exploits the sectarian issue for political purpose which divides the society on the basis of sects, which is a grave threat to the stability of country.

The Shia populations constitute $15-20 \%$ of the population in Pakistan while Sunni's are in majority. They were having smooth relation with Shias in the early 1980s. Both communities lived in peace and in unity when a chain of events created sectarian violence. If we look into the past, in 1974 the anti-Ahmadi movements were started, while they were affirmed as non-Muslim by the parliaments of Pakistan (Anita B. Weiss 1986, also Sadia Saeed 2012). Sectarian conflicts are as old as the country itself but the intensification of these conflicts was observed in the late 1970s and in the early 1980s. Due to internal political changes, Islamic revolution in Iran and reaction of the Arab World give birth to sectarianism in Pakistan (V. Pant 2009, also Mushahid Hussain 1993). 


\section{Sectarianism in Pakistan}

The Sunni and Shia sects are further divided into Sub-sects. Shia sects consist of, such as the Ismailis, the Bohras and the Ithna Asharis (twelvers). Sunnis sects comprise such groups as the Sufi-inspired Barelvi, the Deobandi, and the Wahabi-like Ahl-e-Hadith. In such society rebellious thoughts and experiments can be undertaken without the threats of aggression and violence. Sectarian strife is not only found among the Muslims in Pakistan; it also exists in all other religions of the world. For instance, in Christianity with Catholics verses Protestant, Zionism, Hinduism and Buddhism all these religions are full of sects and sub- sects (Sandano 2011). Attacks in major cities of Pakistan like Karachi, Peshawar, Quetta, Lahore Islamabad Gilgit Baltistan (GB) and the Khyber PakhtunKhwa (KPK) appear as result of division between Sunnis and Shias. Since the last three decades Sunni and Shia extremists from both groups have attacked each other all over Pakistan. However, analysts and scholars are of the view that the numbers of violent incidents currently taking place are by Sunni extremists who are inspired by Al-Qaeda's ideology. In the contemporary scenario, the sectarian violence focus has changed. During 1980s and 1990s the sectarian violence was severe in Karachi and in the area of Sindh.

Pakistan Institute of Peace Studies' annual report on Pakistan's national security in 2010 clearly shows that the incidents and violence of terrorism decreased in Pakistan during 2010, but there was an increase in sectarian and ethnic violence. The figure of sectarian violent incidents in 2010 and 2009 were the same, but the number of casualties, both deaths and injuries, greater than before. A total of one hundred fifty two incidents of sectarian violence, including sectarian-related attacks and clashes, killed six hundred sixty three people, it shows a $50 \%$ rise in causalities compared to 2009 , and injured another 1,569 people, almost three times high than in 2009 (PIPS 2011).

Sectarian violence is not new phenomenon in Pakistan particularly in Punjab, which has been a breeding ground of antagonism between Sunni and Shia for decades. In 1990s, hundreds were killed in SunniShia sectarian violence. The sectarian conflict in Sargodha, Sahiwal, Lahore, Multan, Vehari, Shorkot and Bahawalpur created concern for the law enforcement agencies throughout Punjab. The sectarian violence took place in 1991, from Lahore when the Iranian consulate was killed there because the Sunni SSP leader was murdered in Jhang in 1990s, which used hated wording in his speech against Imam Khomeini (Ahmed 2011).

Jhang had witnessed severe waves of sectarian militancy. The rise of a particular type of Deobandi influence is certainly a factor. Clerics like Haq Nawaz Jhangvi and his successors, who have claimed authority to denounce Shias as non-Muslims, have operated relatively freely in the area, preaching hatred and instigating violence. The antagonism between both important association in Jhang known as Syeds and Sials is counted as a considerable reason. These competing kinships have intentionally violated and provoked the sectarian fault lines in Jhang for local political benefit (The Express Tribunal 2012). In 1996, LeJ emerged as an armed offshoot of the SSP. The SSP expanded its roots in sectarian antagonism and Biraderi politics in Jhang. It structured itself remarkably well at the district and tehsil level. According to an estimate, by the time that the SSP was outlawed in January 2002, it controlled seventy four districts and two hundred twenty five tehsil. In addition, the SSP ran seventeen foreign branches, in countries that included Saudi Arabia, Bangladesh, Canada, and the UK (The Express Tribunal 2012).

The increasing authority of SSP is a sign of an alliance with hostility. As Jhang was the hub of countless sectarian killings, they spread violence to other areas of Punjab and outside. SSP tried to detach itself from the continuation of armed conflicts.

The SSP militants follow two main approaches of operation; killing the people who seem to be a hurdle in its proceedings, known as target killing and indiscriminant shootings in Mosques, Imambarghas, and graveyards while performing sacred activities. SSP was able to obtain modern weapons. Saudi Arabia was the major source of funding, while Iran provided financial support to Shia outfits (The Express Tribunal 2012). The split of sects made SSP widen its coalition. In 1990 the election campaign, held at middle Jhang electorate, Maulana Esar-ul-Qasimi, Haq Nawaz's beneficiary and vice supporter, got victory with a significant majority (The Express Tribunal 2012).

Sectarian violence is not limited to Punjab only. Baluchistan was a peaceful place where people of different sects live together for centuries. Being adjacent to Afghanistan and Iran, this area was influenced by the Afghan Jihad and Islamic Revolution of Iran. The last few years have witnessed the unprecedented killing of innocent people in sectarian violence and ethnic conflicts. In 2005 fifty three were assassinated and fifty seven were wounded in a terrorist attack on a mosque of Shia, during the Friday prayer. Earlier, on 8th June, thirteen individuals of the police who were trainers were assassinated and eight were wounded in Quetta. They belonged tothelocalHazaragroupofShiasect(http://www.satp.org/satporgtp/countries/pakistan/Balochistan/data/incident_20 05.html). This event in Quetta shows an aspect of sectarian violence in Pakistan. Quetta being adjacent to Afghanistan's Kandahar province has been viewed as the terrorist center (Underlying the Causes of Sectarianism 2011). Quetta is among those cities where Shia population is the largest in the Province. Iran's consulate and cultural centre in Quetta became the hub of activities that Iranian government was undertaking. The consulate formed a group of supportive scholars including many Sunni scholars. These scholars visited Iran on a number 
of occasions and vehemently participated in seminars and speeches in support of revolution (Underlying the Causes of Sectarianism 2011). There were many other Sunni scholars against this revolution. There appeared a division within scholars' community both moving apart with more zeal as the battle went on. The two fronts is/were fighting each other, one for the support and other against the revolution.

Uprising of Baluch militants against the state took a new turn in the sectarian violence in this Province. Several groups are working independently for militancy and sectarian violence. It is impossible to separate militant groups from sectarian groups. Recent record of targeted sectarian killings in Quetta city confirms that most of victims were non-local Shia. It is much more convenient for killing a person being 'Shia' than 'nonlocal' as the killing will automatically come under purview of sectarian rather than ethnic issue. The overwhelming majority of Shia are from Hazara community residing in east and west part of Quetta, while few are customarily Baluch and some migrated from Afghanistan. A good majority of the Hazara community also lives in the Pakhtun belt, and not a single clash between the two ethnic groups is reported yet (Underlying the Causes of Sectarianism 2011).

Similarly Karachi the largest city of Pakistan and the capital of Sindh is the hub of different kind of sectarian groups. Sectarian extremists are trained at Madrassas (religious institutes) of Sunni and Shia. In 1950, in Karachi there were only five Madrassas which turned into twenty by 1971. Among those four were Deobandi and one Shia Madrassas (Crisis Group 2005, also Ahmed 1979). According to an estimate, currently 979 out of 2,012 Madrassas are functioning in Karachi. According to the Deobandis they argue that they have 3,000 religious institutions in Sindh in which more than half are in Karachi. It is also claimed that there are 791 religious institutes of Barelvi in Sindh among them 550 are in Karachi and Hyderabad. Hyderabad is second largest city and is Mohajir (migrated from India in 1947) monopoly place. There are 121 Madrassas of Shia among them 36 in Karachi. Ahle Hadith has 56 Madrassas and 30 of them are in Karachi (Monthly Wafaq alMadaris 2004). In 2004, due to terrorist attacks on mosques seventy five casualties occurred, belonging to Shia and Deobandi Sect. Sunni prominent leaders of SSP were killed in response to Shias killing in Karachi. Strikes and violence increased in such retaliations which caused the casualties of both groups to rise.

In Karachi political violence has existed before. In the mid 1990s, Shia Sunni violence also bred through the network of Madrassas (Monthly Wafaq al-Madaris 2004). Up till now, over than five hundred people were assassinated in these sectarian attacks. Shias have to bear the impact of this sectarian violence. As Sunni extremists have directly targeted professionals and forcing them to migrate.

From $11^{\text {th }}$ September 2001, Karachi has been a protected area for al-Qaeda leaders and harbored that organization's partners like sectarian group of Jaish-e-Muhammad (JM) and SSP. According to Taj Haider, who is the central information secretary of Pakistan Peoples Party and also a former Senator, "Terrorists and their mafias need the cover of sectarian, linguistic and political organizations. Terrorists of a certain organization slide into another when their original organization comes under pressure". The US journalist Daniel Pearl was also assassinated in Karachi (Mcgirk 2003).

The North West Frontier Province (NWFP) now KPK is progressively a geographic and ideological hub of sectarianism is also in case in hand. Being on the border of Afghanistan and the Federally Administered Tribal Areas (FATA) has faced a social and political shift for the past thirty years into conservative and confrontational religion. The rise in sectarian killing started in 1992 when 15 people were killed in Peshawar during Ashura procession. Into response the Shia burnt tires of vehicles, looted banks, and damaged the public property. The Shia representative organization TNFJ declared it anti Islamic practices (Haleem, 2003).

In 2002, in KPK Muttahida Majlis-e-Amal (MMA: religious coalition) got overwhelming electoral victory which was dominated by conservative leaders (Nasr 2000). During MMA's rule surprisingly few sectarian incidents were recorded. Over all, the coalitions take up judicious style for Shia minority. Even they did their best to counter intra-Sunni confrontations between Deobandis and Barelvis which was rooted in Khyber agency (Khan 2007). The minority groups did not find problematic during in the Frontier stated that the MMA's rule. They admired the official efforts of the Islamist management. On the other hand during MMA they were also frustrated by the inclination to propagate conservative values as it increased societal pressures on groups who don't want to follow the Deobandi norm.

There are certain parts of Pakistan where the Shia population is large in numbers, like in the tribal agency of Kurram where they constitute $80 \%$ of total population. In Gilgit in the Northern areas, they constitute $60 \%$ of the population (Ahmed 2011). Most of sectarian violence is noticed in these areas of KPK. The following are some factors responsible for sectarian strife in Pakistan.

\subsection{Zia Islamization Policy}

IV. Internal and External Factors of Sectarianism in Pakistan

Zia's Islamization Policy is/was a factor of sectarian conflict in Pakistan. He was totally in favor of an Islamization policy and during his period many Madrassa (religious seminaries) were established. Conflicts between Shia and Sunni sects become organized during his regime. Zia introduced the Islamic Sharia law, 
which devastated the bond of unity between Shia and Sunni community. The obligation of zakat by Zia-ul-Haq, in 1980s, was resisted by Shia. Mufti Jaffar Hussein the prominent leader of the Shia supposed that if Pakistan was to have its own Islamic law then the Shia should be allowed to follow its own Fiqa (Hudson Institute 2006). It clearly showed that the Shias of Pakistan were inspired by the Iranian Revolution and refused to accept the Sunni based Sharia laws and demanded their own recognition as a different denomination in Islam.

\subsection{The Iranian Islamic Revolution}

The Islamic revolution in Iran had great influence on its neighboring countries. The Shia communities get organized due to this revolution. Iran supported the Shia groups of Pakistan and a Shia version of new militancy emerged. The Shia institutions especially in Khurram Agency, Hangue, and Peshawar district got assistance from Iran. Islam was divided by sectarianism through Iranian Shia and Arab Sunni. Iran and Saudi Arabia share a couple of advantages; both have petro dollars they can use to finance their campaigns both draw religious sectarian and ethical appeal to pre-empt ready- made blocks of supports (http://pksecurity.blogspot.com/2012/07/iran-saudi-arabia-and-pakistan-make.html).

\subsection{Conservative Saudi Arabia and Other Muslim Countries}

Saudi Arabia other Muslim countries and NGOs funded the Sunni group in Pakistan against Iranian inspired activitism. This rivalry between the two Islamic countries led Pakistan towards sectarian strife between the Sunni and Shia groups. During that time LJ, the most violent Sunni organization was formed. In fact, the controversary between the two Islamic countries the Iran and Saudi Arabia, with two different sects failed to comprehend that their clash would create insecurity in the other Muslim countries.

\subsection{The Iran-Iraq War}

The Iran-Iraq war which continued for eight years also weakened the position of other Muslim countries and induced the aspect of sectarianism. The consequences of Iran-Iraq war was also seen in Pakistan, which become a battlefield of Sunni dominated regime of Saddam Hussein and Shia state of Iran. Both countries funded their proxies in Pakistan who used the sectarian card for their own interest. In addition, Pakistan became a battleground for Iran and Saudi Arabia of supporting their relevant sects with funds in shape of money (http://pksecurity.blogspot.com/2012/07/iran-saudi-arabia-and-pakistan-make.html). The external powers intervention led Pakistan towards sectarian violence.

\subsection{The Soviet Union Invasion of Afghanistan}

The Afghan Crisis played a vital role in the rise of sectarian strife in Pakistan. The Soviet invasion worsened the situation in Pakistan when the United States fought a proxy war for containing Communism in this region. The US assisted Pakistan financially and militarily which gave rise to radicalization in the society. During that time, many organizations were formed in Pakistan like Jamiat Ulima-e-Islam (JUI), organized the Sipah-e-Sahabah Pakistan (SSP) in 1985 and the Lashkar-e-Jhangvi (LeJ), while adherents to the Ahl Hadith school of thought organized the Lashker-e-Taiba (LeT) in 1987. Mujahidin who were recruited against the Russian forces were Sunni. The Shias began to fear that the balance of population was in favor of Sunnis as a result of the influx of heavy armed in Sunni Afghan refugees. The Shias organized its militia with the name of Sipah-e-Mohammad Pakistan (SMP) in 1991 (Moonis Ahmar and Ali Riaz 2005).

The Afghanistan Crisis since 1979-till date posed alarming threats to the domestic and external security of Pakistan, because of the enormous arrival of Afghan refugees in Pakistan which culminated in the spread of terrorism; militancy and extremism; the Talibanization of Pakistani society and ethno-political crisis in Karachi and in the province of Baluchistan started after 9/11. In addition, Pakistani society has also suffered from a huge supply of drug and narcotics, Kalashnikov culture, and lawlessness due to the Afghan crisis (Nasar Dotani 2011).

It is a common phenomenon that whenever a war erupts on a large scale in any country, its fallout is felt in its immediate neighboring countries as well. Afghanistan is not an exception (Talat Hussain 2010). Three decades of unabated war left unprecedented repercussions not only on Afghanistan but on its neighbors as well. However, Pakistan being a front line state, on both the occasions, against the expansionism of communism and the war on terror after $9 / 11$ is also badly affected by the Afghan imbroglio, as compared to other neighbors. Being a partner in the war against terrorism Pakistan has to face difficulties at home due to Talibanization in society. Talibanization promoted the culture of terrorism; it also gave rise to the ethnic conflicts and sectarianism in Pakistan (Nasar Dotani 2011).

\subsection{Role of Religious Groups in Sectarian Violence}

Sectarianism is often attached to religion since it is the factor that makes an attitude, an action, a belief, or a structure specifically sectarian as opposed to being simply generally bad or destructive" (Liechty and Clegg 
2001). Sectarian groups are always attached to a religious discourse. Due to the narrow-minded of religious leaders the level of intolerance among religious groups in our society is growing. The dilemma in Pakistan is that religious intolerance and extremism has obtained militant overtones. Bitter hatred towards members of diverse sects is not only preached but also overvalued. Thus, it has threatened the peace and security of the country.

The religious leader's particular meeting points are holy places like Mosques, Imambarghas, or religious rallies. This is not the only type of sectarian violence, but it is the most noticeable type opening up the chance of anyone belonging to the opposing sect to be a target. This process of targeting holy places is one of the strongest communicating mechanisms. By using violence and targeting holy places both sects convey a message of hatred against each other, which not only creates danger but also further divide the individuals on the bases of sects. They do not only use holy places for this purpose but are also targeting individuals by highlighting killings just for publicity and for gaining sympathies of masses ( Satu P Limaye et al. 2004).

The technique and method of violence have altered within the previous two decades. Famous figures and other prominent members of other sects, whether they are doctors, businessmen or worshippers, in mosques or religious processions have been the target. Violence is now also targeted at government institutions, law enforcement officials, and other professionals for either their sectarian identity or involvement in sectarian cases. Sectarian violence has also adopted new methods in other conflict areas involving Muslims (Behuria2004).

These religious organizations belong to different sects and promote and protect their own sect. They neglect each other's holy days and their rivalry assumes more aggression even during holy events. They proceed on the line of tit for tat. If the Shias attack on Sunni Mosque the Sunni will settle the score. Different religious leaders were killed which include Tehrik Nafaz-e-Fliqh-e- Jaffariya (TNFJ) chief Allma Arif Husseini, SSP chiefs and founders Maulana Haq Nawaz Jhangvi and Zia-ur-Rehman Farooqi. Sunni groups blamed Shia for publishing hatred material in books against Sahaba Karams (Riikonen 2007). SSP claims that they are not involved in any sectarian conflict and have no relation with LeJ. This blame game against each other increased the atmosphere of terror and insecurity in Pakistani society.

\section{Sectarianism: Implications for Pakistan Security}

Sectarianism is a real threat to the security of Pakistan. It has shaken the basic foundation of Pakistan and has created disturbance, violence, hatred and disorder in society. From last three decades sectarian conflicts have increased suicide bombings, bomb blasts, assassinations, and terrorist attacks. Although Pakistan has threats from India from time to time, but the immediate threat is sectarian strife.

There are different opinions of the scholars about the severity of the internal threats to Pakistan from sectarianism as it is weakening the roots of the society. After the Soviet invasion of Afghan war Pakistan was led towards sectarian conflicts and the society was divided. Saudi Arabia financially supported the Sunni whereas Iran aided the Shia community in Pakistan. These ideological differences gave birth to sectarian strife in Pakistan which threatened the security of Pakistan.

Sectarianism has spread in Pakistan to such an extent that number of people are losing their lives. According to the South Asia Terrorism Portal 2009 report, from to 2002-08, there are a total of 642 sectarian violence incidents that occurred in which 1,518 people were killed and 2,817 people were injured (South Asian Terrorism Portal 2009 report 2012). Pakistan is an Islamic state, but different religious political leader exploit religion for their own interest and divide the society into different sects. Islamic fundamental parties of Pakistan are also active in Kashmir and Afghanistan. The extremists got education from these Madrassa. These extremists also provide arms to Sunni operating in Pakistan killing Shia and as a retaliation Shia killing Sunni.

Pakistan's soft image has been ruined due to the sectarian violence which has directly impact on the economy because foreigners refrain from investment in a destabilized state. Due to this unemployment are high even educated people did not find desired jobs. These people are exploited by extremists by providing money to them against the state. These things destabilize the country and are great threat to security. Initially sectarian conflicts were just confined to religious leaders, but now there is organized killing through suicide bombings on mosques and processions. Sectarian strife has created an alarming situation in the country.

Almost all south Asian states including Pakistan continue to experience terrorism, sectarianism, religious, ethnic and political violence. The state is unable to provide security which resulted in the 'Privatization of Security' where 'Small Arms' and 'light weapon' have become main tools of violence in ethnic and other internal conflicts by both state and non-state actors (Cheema 2006) which threatened the life and prosperity of innocent people. In these conflicts numbers of casualties occurred which has threatened the very existence of life. Though, national security is paramount, but without human security it cannot be achieved. It is the responsibility of a state to protect its individuals from the evils of sectarian and ethnic conflicts. 


\section{Policy Recommendations}

There is an imperative need to tackle sectarian violence. It seems that there is a lack of vision and strategy to tackle this menace. Contemporary when our problems are fully built up and the way out is not visible, we have to find the solution of our problems. There is a need to take short-term and long term doable initiative. There are certain initiatives if Pakistan adopts them it can improve its sectarian conflicts and can get rid of this menace in the long run.

- Islam teaches us peace, tolerance and strictly prohibits use of force in spreading its message. It promotes love and peace and to leave in harmony with others and those who resort to violence are not true Muslims and such people deserve harsh punishment.

- The constitution of Pakistan must be implement in full sprit as it does not discriminate on the basis of color, race, or creed and give full freedom of expression, association, and assign duty to respect fellow Pakistani. On the other hand sectarianism divides us in 'us' and 'they' instead of uniting.

- Sectarian violence is more political than a religious problem and politician must solve this menace by political means rather than through violence.

- Pakistan needs true democracy having competence and authorization to solve the issue harmoniously because democratic governments tend to be more open, flexible, and liberal.

- Government makes gigantic claims to curb sectarian killing but there is hardly any serious effort to resolve the issue. It assumes heavy responsibility to resolve this menace as it has all necessary resources.

- If killing of people is solution to the problem, then high death rates in sectarian killings in recent years should help settle the issue but that has not (Tribune 2012). Contrary to it, it has inflated the conflict which is in favor of nobody. We must denounce extremism and, at least, live together as do normal human beings.

- There is a dire need of overhauling of judicial system, police and law and order agencies. Government should also make accountable its intelligence organizations. People are of the opinion that these organizations are directly involved in sectarian violence and their activities must be checked.

- Government should initiate economic policies which will help in reducing poverty and unemployment. This will enable people not to resort towards extremists organizations for there financial support.

- Media play their role in curbing sectarianism. They must report what is true and avoid yellow journalism. They can also guide and educate people as most of people have access to media especially electronic.

- Education system of Pakistan needs revision. It should teach tolerance, human rights, respect of other religions, and to live with love and peace with fellow beings.

- Religious parties have the responsibility to propagate religious harmony and cut off there militant groups because most of the sectarian organizations are religious based.

- The role of civil society is also of immense important in this regard because it has access and roots in masses. They can educate people and bring awareness in them.

- Ultimately, religious radicalism is not simply a law and order problem. At its core are questions about the very nature of the Pakistani state. Pakistan president General Zia's in the 1980s, introduced status laws that discriminate between citizens according to religion, sect and gender. Therefore government should repeal religious laws that undermine genuine rule of law and promote religious extremism.

- Religion should not be used for political gains because exploitation of religious sentiments is highly tempting and a very effective tool for public mobilization. Some of the worst crimes against humanity have been committed through such manipulation. Religious violence is related to Muslim outrage against perceived injustice being perpetrated all over the world. There is a dire need for just and expeditious solutions to Muslim problems around the world.

- There is a need for social reforms in the country, ensuring free education for all at least at the primary level with incentive to poor children and various income generation measures should be taken this would help to contain violence in society.

- There is also a need to create religious harmony among different sects and to give respect to each others holy events.

- Pakistan is not just a multi-ethnic and multi-linguistic state but represents a significant mosaic of cultural, sectarian and religious diversity. This diversity need to recognized and promote unity. There is a need to promote education among the misguided youth that violence is not solution to their demand. Promote the research on conflict resolution focusing on religious and sectarian violence ((Tribune 2012)).

- To stop the proliferation of arms race because it increases the risk of violent conflict between dissenting groups. Violence and crimes in movies is a recognized source of real world crime and violence. The impact of such movies on youth remains understudied and needs to be critically evaluated.

- Reforms of Madrassas education are important to mainstream Madrassas and their curriculum is required to prevent the spread of hatred against other sects, religions, and societies. Religious scholars of different sects need to work collectively to help to diffuse the religious and ethnic violence and promote the message of 
love and peace to humanity. All institution of the state, civil society and the public at large must join hands to counter the violence in Pakistan.

\section{Conclusion}

History shows that central authority can only be effective if it is strictly delimited. Regrettably, Pakistan has been what 20th-century European 'segmentary' society. Hovering between centralization and anarchy, society is typified by a regime that drains the life from a region. Because of its own fragility it fails to establish lasting institutions. It is a place where tribes are strong and the central government is comparatively weak (Kaplan 2012). This may be the reason that sectarianism dramatically increased in Pakistan after General Zia's dictatorship.

Sectarianism is just a symptom not a disease which cannot be cured. Media, political parties, and religious groups have to play a significant role to diminish this evil from society. State, society and individuals are the three main parameters of a country. The government should take initiative to tackle the issues of poverty, unemployment and good governance. For the improvement of internal security there is a need to involve the civil society in internal affairs. In return, civil society should play its positive role for the peace and harmony in the state. Pakistani need to think as being a Pakistani not like belonging to different sects and as a Sindhi, Baluch, Punjabi or Pakhtun, then neither the internal nor the external powers could dare to harm the unity of the nation.

\section{Acknowledgment}

We are thankful to faculty members of International Relations at Quaid-i-Azam University Islamabad, National Defence University and the reviewer at University of Malakand Pakistan for validation of the paper.

\section{References}

[1] R. Ballard, "Negotiating Race and Ethnicity: Exploring the Implications of the 1991 Census", Patterns of Prejudice, 1996, Pp.30 33. As well John Hutchinson, and Anthony D. Smith, Introduction, In Ethnicity, edited by J. Hutchinson and A. D. Smith, Oxford University Press, Oxford and New York, 1996, Pp. 1-14.

[2] Bryan Wilson, Religion in Sociological Perspective 1982, Oxford University Press page 89 'In English, it is a term that designates a religiously separated group, but in its historical usage in Christendom it carried a distinctly pejorative connotation. A sect was a movement committed to heretical beliefs and often to ritual acts and practices like isolation that departed from orthodox religious procedures'.

[3] McCormick Maaga, Mary excerpt from her book Hearing the Voices of Jonestown, Syracuse University Press, 1998.

[4] Andrew Feenberg, "Paths to Failure: The Dialectics of Organization and Ideology in the New Left", Humanities in Society, 1983, p.8.

[5] Ibid.

[6] Sadia Saeed, "States, Islamist Movements and Muslim Politics: Explaining the Pakistani State's Shift from Accommodation to Exclusion of the Ahmadiyya Community", available at http://www.yale.edu/ccr/SAEED.pdf, p.2, acceesed on June 23, 2012, as well Anita B. Weiss, "Islamic Reassertion in Pakistan: The Application of Islamic Laws in a Modern State, Syracuse University Press", (Ed.) 1986.

[7] Mushahid Hussain, "Pakistan-Iran Relations in the Changing World Scenario: Challenges and Response", Foreign Policy Debate: The Years Ahead, Islamabad: Institute of Policy Studies, 1993, Pp. 215-9. As well Harsh V. Pant, "Pakistan and Iran's Dysfunctional Relationship", Middle East Quarterly, spring 2009, pp. 43-50.

[8] Sectarianism in Pakistan "Current Trends in Islamic Ideology Vo.4, November 01, 2006, Hudson Institute's Center for Islam, Democracy and the Future of the Muslim World.

[9] Iran, Saudi Arabia and Pakistan Make a Difficult Triangle, National Security, Monday, July 30, 2012, Available At http://pksecurity.blogspot.com/2012/07/iran-saudi-arabia-and-pakistan-make.html, accessed on August 10, 2012.

[10] Ibid, p.102.

[11] Moonis Ahmar, "Sectarian Conflicts in Pakistan", Pakistan Vision Vol. 9, No.1, p. 4. As well Ali Riaz, "Global Jihad, Sectarianism and the Madrassas in Pakistan", No. 85, Institute of Defence and Strategic Studies Singapore (IDSS), AUGUST 2005, p. 10.

[12] Abdul Nasar Dotani, Assistant Commissioner Government of Baluchistan, Pakistan, “ The Impact of Afghan crisis on Pakistani Society since 1979 till date", Paper Presented at the International Conference, Doshisha University, Kyoto, Japan, September 1819, 2011.p.6-7.

[13] Talat Hussain, Afghanistan's complex situation and its implications on Pakistan, Master thesis, p.11

[14] Abdul Nasar Dotani, p.9.

[15] Joseph Liechty \& Cecilia Clegg, "Moving Beyond Sectarianism”, Dublin: Columba Press, 2001, p. 38.

[16] Edited by Satu P Limaye, Mohan Malik, Robert G. Wirsing, Asia-Pacific Center for Security Studies Honolulu, Hawaii, Chapter 7 Suroosh Irfani , "Pakistan's Sectarian Violence: Between the "Arabist Shift" and Indo-Persian Culture, Religious Radicalism and Security in South Asia, (2004), Pp.147-169.

[17] Ashok K. Behuria, "Sunni-Shia Relations in Pakistan: The Widening Divide”, Strategic Analysis, Vol. 28, No. 1, Jan-Mar 2004, p. 167.

[18] Katja Riikonen, "Sectarianism in Pakistan: A Destructive Way of Dealing with Difference", Pakistan Security Research Unit (PSRU), 1st March 2007 p.3.

[19] Imran Ali Sandano, "Pakistan under the Curse of Sectarianism", Analysis, April 21, 2011.

[20] Pakistan Security Report 2010, Pak Institute for Peace Studies (PIPS), January 2011, p.15.

[21] Khalid Ahmed, Sectarian War Pakistan's Sunni-Shia Violence and Its Link with Middle East, Oxford University Press New York, January 2011, p.164. 
[22] "In the 'name' of God: Violence erupts in sectarian hotbed", The Express Tribunal, December 6, 2011, available on http://tribune.com.pk/story/302869/in-the-name-of-god-violence-erupts-in-sectarian-hotbed/, accessed on February $12,2012$.

[23] Ibid, p.168

[24] Ibid, p.169

[25] Ibid, p.170

[26] Terrorism Related Incidents in Quetta 2005http://www.satp.org/satporgtp/countries/pakistan/Balochistan/data/incident 2005.html, accessed on $31^{\text {st }}$ July 2012

[27] UnderlyingtheCausesofSectarianism,https://docs.google.com/viewer?a=v\&q=cache:jb3NddGe3WsJ:cpdbalochistan.org/PDF/Und erlying $\% 2520$ Causes $\% 2520$ of $\% 2520$ Sectarian $\% 2520$ Violence.pdf + sectarian+violence $+\mathrm{in}+$ multan \&hl=en \& gl=pk\&pid=bl \&srcid= ADGEEShfy0Isc2xHbIWg63JoWRW1ka73MAOwqzmNUKiVfvaIBBLAQOw6s3dn9dPjsHyW7XhOebFhEH1_B5LWdwCJO1 Lr aor8Pfm08eOaClommWgFjFDcU91c F7s1TQ HbjoksCozyM\&sig=AHIEtbTnHkw2PzclrCpHCZQZHzK5H3NO9w accessed on December 19,2011.

[28] Ibid

[29] Ibid

[30] The State of Sectarianism in Pakistan, Asia Report Nº5, Crisis Group, 18 April 2005, p.11. See also Hafiz Nazar Ahmed, "Jaiza: Madaris-e-Arabia in West Pakistan" (Muslim Academy, Lahore, 1972); "Report of the National Committee for Deeni Madaris in Pakistan", Ministry of Religious Affairs, Government of Pakistan, Islamabad, 1979; Directory of Deeni Madaris, Ministry of Education, Islamabad, 2003; Wafaq al-Madaris (Urdu), August 2004; and Crisis Group Report, Madrasas, Extremism and the Military op. cit. There are no definitive statistics for mosques, although officials and ulema believe there are anywhere between 250,000 and 300,000

[31] Monthly Wafaq al-Madaris, August 2004, p. 63; Crisis Group interviews with representatives of Madrassa unions

[32] Ibid, p.12.

[33] Tim Mcgirk Who Killed Daniel Pearl? Time Magazine World, Jan. 27, 2003

[34] Thematic Chronology of Mass Violence in Pakistan, 1947-2007, Haleem, 2003: 469, available at http://www.massviolence.org/Thematic-Chronology-of-Mass-Violence-in-Pakistan-1947-2007?artpage=8-12, accessed on July 12, 2012.

[35] Seyyed Vali Reza Nasr, "The Rise of Sunni Militancy in Pakistan: The Changing Role of Islamism and the Ulama in Society and Politics," Modern Asian Studies, Vol. 34, No. 1 (2000), p. 157. As well Joshua T. White, "Pakistan's Islamist Frontier: Islamic Politics and U.S. Policy in Pakistan's North-West Frontier", Center on Faith and International Affairs, Pp.147-84.

[36] Ismail Khan, "Govt's Writ Weakening in NWFP, Tribal Areas," Dawn, Lahore/Karachi/Islamabad, March 29, 2007;

[37] Khalid Ahmed, Sectarian War, Narrative of Fearful Asymmetry, Karachi; New York: Oxford University Press, 2011, p.160, also available on http://searchmobius.org:2082/record=b25361890 S0, accessed on January 03, 2012.

[38] South Asian Terrorism Portal 2009 report http://www.satp.org/satporgtp/countries/pakistan/index.htm , accessed on July 31 , 2012.

[39] Pervaiz Iqbal Cheema, "Political Violence and Terrorism in South Asia", Islamabad Policy Research Institute (IPRI) Publication, 2006 , p.6.

[40] At least 25 Gilget Shias killed in Mansehra sectarian attack", Tribune, August 16, 2012, available at http://gbtribune.blogspot.com/2012/08/at-least-gilgiti-shias-killed-in.html, access on August 20, 2012.

[41] Ibid

[42] Robert D. Kaplan, "What's Wrong with Pakistan?", Foreign Policy Journal, July/August 2012 available at http://www.foreignpolicy.com/articles/2012/06/18/whats_wrong_with_pakistan?page=0,3 accessed on August 10, 2012. 